\title{
ДОСТОЕВСКИЙ О ПОЛЯКАХ - ПОЛЯКИ О ДОСТОЕВСКОМ: МЕТАСТЕРЕОТИПНОСТЬ КАК ИМАГОЛОГИЧЕСКАЯ ПРОБЛЕМА
}

\author{
FYODOR DOSTOYEVSKY IN JERZY STEMPOWSKI'S RECEPTION: \\ THE IMAGOLOGICAL ASPECT
}

\author{
ЛЕОНИД МАЛЬЦЕВ
}

\begin{abstract}
In the article, Jerzy Stempowski's essay The Poles in Novels by Dostoyevsky is analyzed in terms of its imagological aspect. Polish motifs in the novel The Brothers Karamazov are investigated in connexion with the writer's religious philosophy and existential consciousness.
\end{abstract}

Леонид Мальцев, Балтийский федеральный университет им. Иммануила Канта, Калининград - Россия, lamaltsev23@mail.ru

Статья представляет собой опыт анализа эссе Ежи Стемповского Поляки В романах Достоевского в теоретическом аспекте имагологии. Подробно рассматриваются польские мотивы в романе Братья Карамазовы в соотношении с религиозной философией и экзистенциальным самоощущением писателя.

В самосознании народа предметом особого интереса является его образ в глазах „других". Совокупность этих отображений, непосредственных и производных, изучается в гуманитарных науках в неразрывной связи со стереотипией, которая является одним из возможных способов ментального упорядочивания окружающей действительности, зачастую не поддающейся либо мало поддающейся объективному и всестороннему объяснению и описанию. Как устойчиво-закостенелая форма, стереотип может быть болезненно и даже раздражительно чувствителен по отношению к любому нестандартному мнению, так как, по емкой метафоре У. Липпмана, стереотип является „бастионом нашей традиции, и, укрывшись за стенами этого бастиона, мы можем чувствовать себя в безопасности" 1 . В крайнем случае ломка стереотипов провоцирует крах самой идентичности, в более мягких вариантах - приводит к корректировке устоявшихся мнений либо к адаптации по отношению к изменившимся внешним условиям.

1 У. Л и п п м а н, Общественное мнение, Москва 2004, с. 109. 
Для литературоведческой имагологии ${ }^{2}$, наряду с понятием стереотипа, продуктивно понятие „метастереотип”, определяемое как „представление человека о стереотипах другой группы относительно своей" 3 . Без аспекта метастереотипности русско-польская имагологическая „картина" представлялась бы неполной, поскольку, занимаясь стереотипностью как таковой, исследователь русско-польских отношений в большей или меньшей степени касается вопроса, как тот или иной стереотип, возвращаясь в сферу бытования „своего”, „родного”, модифицирует наши представления и о своей собственной культуре, и о культуре другой, продуцирующей стереотипы с той или иной эмоциональной окрашенностью.

В русской классике и ее рецепции на Западе метастереотипный прецедент создают нелицеприятные образы поляков в творчестве Федора Михайловича Достоевского и связанное с этим нередко негативное отношение польского реципиента не только к отдельно взятым "антипольским" эпизодам, но и ко всему творчеству русского писателя. В качестве примера приведем высказывание крупного польского прозаика конца XIX - начала XX века Стефана Жеромского, который, испытав очевидное творческое воздействие со стороны Достоевского ${ }^{\text {, }}$ в очерке Снобизм и прогресс (Snobizm i postę) назвал его не иначе как „duchowym ojcem czarnej sotni, czysto moskiewskim mistykiem, zaciekłym prorokiem" 5 .

Эту отрицательную слагаемую польского образа Достоевского следует воспринимать довольно специфической составной частью исторически сформировавшегося образа Достоевского на Западе. В свою очередь, отраженный образ „западного” Достоевского, не отделимый от идей и образов Ницше, Кафки, французских писателей и философов-экзистенциалистов и многих других видных представителей западной культуры, не тожествен собственно „русскому Достоевскому”,

\footnotetext{
2 Имагология как направление литературной компаративистики получила развитие в России начала XXI века в работах видных литературоведов разных направлений, см.: В. А. Х о р е в, Польша и поляки глазами русских литераторов. Имагологические очерки, Москва 2005; В. Б., 3 е м с к о в, Образ России „на переломе” времен (Теоретический аспект: рецепция и репрезентация „другой” культуры), „Новые российские гуманитарные исследования" 2006, № 1; Н. П. М и х а л ь с к а я, Россия и Англия: проблемы имагологии, Москва 2012.

${ }^{3}$ См. Т. Н е л ь с о н, Психология предубеждений. Секреты шаблонов мышления, восприятия и поведения, Санкт-Петербург 2003, с. 218.

${ }_{4}^{4}$ См., напр.: А. И. Б а р а н о в, Стефран Жеромский и Ф. М. Достоевский, [в:] Литературные съязи славянских народов, Ленинград 1988.

5 S. Ż e r o m s k i, Snobizm i postęp, [в:] электронный ресурс: http://literat.ug.edu. $\mathrm{pl} /$ xxx/snobizm/0002.htm (18.12.2015).
} 
взгляды которого - идеологические, психологические, этические и религиозные - нельзя рассматривать иначе, как в контексте общественного и духовного климата России XIX века, сформировавшего творческую личность Достоевского.

Наднациональной тенденцией интерпретации Достоевского не только в русской, но и в западной культуре является его метастереотипизация. Не ставя задачу раскрывать все ее компоненты, назовем существенно важные для данного исследования: во-первых, представление о Достоевском как о „жестоком таланте”, исходящее от одноименной статьи Николая Константиновича Михайловского, и происходящие отсюда далеко идущие выводы о садистических интенциях русского писателя; во-вторых, утрированное представление о Достоевском как „Ницше до Ницше” и, думается, излишне категоричный вывод о том, что Достоевский еще до Ницше взрыхлил почву для „переоценки ценностей", изменившей духовный облик России и Европы в XX веке 6 . Фактором, порождающим метастереотипность в восприятии Достоевского, является свойственная и русской, и западной рецепции тенденция отождествления взглядов писателя с идеями персонажей-парадоксалистов из Записок из подполья и Дневника писателя, а также Раскольникова, Кириллова, Ивана Карамазова, Великого Инквизитора.

Специфика польской традиции рецепции Достоевского в том, что она, следуя в русле западной традиции „раздвоения” Достоевского - художника-мыслителя всемирного значения и националистически настроенного идеолога-публициста, характерна вполне предсказуемой и понятной чувствительностью к „ксенофобскому”, прежде всего, „полонофобскому” сюжету. Например, Гжегож Пшебинда, говоря о публицистике Дневника писателя, заявляет следующее: „Достоевский выступает как отъявленный националист и популяризатор идеи великой Российской империи, враг немцев, поляков и евреев"7. В исследовании Яцека Углика категорически утверждается: „для Достоевского поляки представляли собой один лишь этнографический материал"

На этом фоне выделяется - источниковедчески и аналитически - исследование Марка Ведеманна, освещающее историю польской рецепции Достоевского в XIX веке и отличающееся тонкостью подхода к природе „польского вопроса” в творчестве Достоевского. Как попытку ревизии бытующих в польско-русском дискурсе метастереоти-

\footnotetext{
${ }_{6}^{6}$ См. по этой проблеме анализ В. В. Дудкина: В. В. Ду д к и н, Достоевский - Ницще (Проблема человека), Петрозаводск 1994.

7 Г. П ш е б и н д а, Между Краковом, Римом и Москвой. Русская идея в новой Польше, Москва 2013, с. 81-82.

8 Я. У г л и к, Образ поляков в романах и публицистике Ф. М. Достоевского, “Toronto Slavic Quaterly”, summer 2011, no. 37, с. 142. Курсив автора цитируемой публикации.
} 
пов можно охарактеризовать полемическую сверхзадачу монографии - оспаривание

efektownej, lecz niepodpartej żadnymi dowodami tezy Aleksandra Brücknera, jakoby po roku 1831, a zwłaszcza po 1863, wskutek zaostrzenia się konfliktu rosyjsko-polskiego ,już nie tylko książki, ale całą wielką literaturę wielkiego narodu wstawiono u nas niby na index librorum prohibitorium"

В связи с „польским" сюжетом в творчестве Достоевского вызывает особый интерес и побуждает к размышлениям опыт писателей и эссеистов XX века ${ }^{10}$, нередко состоящий в том, чтобы путем рефлексии найти „третий путь”, путь комплементарности двух правд - польской и русской, исходящий из более общего и, кажется, бесспорного утверждения, что истина сложна, богата оговорками и оттенками, и подчас неуловима и невыразима в слове.

Прежде всего речь идет об эссе Ежи Стемповского Поляки в романах Достоевского (Polacy w powieściach Dostojewskiego). В этой работе, датированной 1931 годом, эссеист производит весьма остроумный опыт стыкования частного и общего - польской темы, занимающей в прозе писателя определенное место, с базовыми положениями его религиозно-философской словесности. Не высказываясь прямо, Стемповский затрагивает одну из смысловых доминант православной традиции в творчестве Достоевского - идею апокатастасиса, понятого как всеобщее прощение грешников и восстановление райского догреховного состояния тварной природы. Например, в романе Братья Карамазовы отголоски этой мысли есть в многочисленных повествовательных вставках - в жизнеописании старца Зосимы, рассказанном им самим, в кратком пересказе Иваном древнерусского апокрифа Хождение Богородищы по мукам, в „басенке" Грушеньки о луковке, в народной „легенде" о сошествии Христа в ад, пересказанной ямщиком Андреем. Соотнося сложную концепцию апокатастасиса с прямолинейным решением польской темы у Достоевского, Стемповский вполне осознанно ставит мировоззренческие постулаты Достоевского на грань нонсенса:

Czytelnik jednak odnosi zupełnie określone wrażenie, że z ogólnego zbawienia wszystkich upokorzonych - Marmeładowa, generała Iwołgina, kapitana Lebiadkina - zostanie zrobiony jeden wyjątek i że tym wyjątkiem będą właśnie Polacy”, для которых вообще „nie znajdzie się miejsca w łodzi zbawienia metafizycznego".

${ }^{9} \mathrm{M} . \mathrm{W}$ e d e m a n n, Polonofil czy polakożerca. Fiodor Dostojewski w piśmiennictwie polskim lat 1847-1897, Poznań 2010, c. 10.

10 См. об этом: В. А. Х о р е в, Ф. Достоевский В сознании польских писателей ХХ века, [в:] его же, Восприятие России и русской литературы польскими писателями. Очерки, Москва 2012, с. 71-98. 
Достоевский о поляках - поляки о Достоевском: метастереотипность...

И дальше:

W fantastycznym świecie Dostojewskiego Polacy zajmują miejsce podobne do tego, jakie w twórczości Nietzschego zajmuje ostatni, najszpetniejszy człowiek, którego widok napełnia Zaratustrę wstydem i podpowiada mu same tylko myśli w rodzaju następującej: „Powiadają mi, że człowiek samego siebie kocha: och, jak wielka musi być ta miłość siebie! Ileż wzgardy ma ona przeciw sobie... Człowiek jest czymś, co przezwyciężone być musi"11.

Этот тезис следует рассматривать как построение Стемповского на основе синтеза идеологем Достоевского и Ницше, но не имманентно присущее мировоззрению Достоевского. Это предпринятый в духе Достоевского эксперимент, который можно назвать испытанием идеи. В отличие от христианской идеи апокатастасиса, приоткрывшейся в образах романа Братья Карамазовы, комбинированная идея Ницше-Достоевского, переконструированная польским автором, имеет ярко выраженную антихристианскую, если можно так сказать - националистическо-метафизическую, направленность.

Исследуя причины этого религиозно-идеологического комплекса, имеющего лишь видимое отношение к мировоззрению Достоевского, Стемповский обращается к экзистенциально-трагической концепции Льва Шестова, развернуто изложенной им в работе Философия трагедии "Достоевский и Ницище":

Jeden z jego (Dostojewskiego - Л. M.) najgłębszych znawców, Lew Szestow, którego Kraków miał zaszczyt gościć w swych murach przed kilku miesiącami, zauważył słusznie, że w powieściach Dostojewskiego okropności jest więcej niż w samej rzeczywistości.

Парафразом философии Шестова является утверждение:

Swój ogromny talent wizjonera koszmarów (Dostojewski - Л. M.) położył w poprzek drogi wytyczonej przez rozsądek i tradycję. Mowa jego jest ostrym krzykiem człowieka rozkazującego nam wracać do Podziemia, akceptować niegodziwość życia bez omówień i uogólnieńn ${ }^{12}$.

В русле Шестова Стемповский утверждает, что антиморалистические постулаты Достоевского-Ницше заключаются в отказе от любого промежуточного утешения, в касании дна отчаяния и в фантастическом обретении спасения и жизни вечной: „odrodzenie prawdziwych potępionych, zgubionych niepowrótnie nie może odbywać się inaczej jak wzorem Feniksa, z niczego"13. Стемповский допускает, что поляки, находив-

11 J. S t e m p o w s k i, Polacy w powieściach Dostojewskiego, [в:] его же, Eseje dla Kassandry, Gdańsk 2005, с. 283-284. Курсив автора цитируемой публикации.

12 Там же, с. 293-294.

13 Там же, с. 297. 
шие метафизическое оправдание собственным страданиям в идеологии мессианизма, могли негативно восприниматься Достоевским именно с точки зрения „подпольной” философии, о которой говорит Шестов.

Стемповский редуцирует художественную философию Достоевского до „философии трагедии” Шестова, не рассматривая возможность контрпозиции, т.е. другие варианты интерпретации религиозной философии Достоевского, в том числе экзистенциальную концепцию Николая Бердяева. Из поля зрения Стемповского выпадает христианство старца Зосимы, связанное с православными корнями мировоззрения Достоевского. Этот „зосимовский” аспект художественной философии колеблет утверждения Стемповского о чуждости Достоевского идеям космической гармонии, поскольку мировоззрение Зосимы основывается на представлении о жизни как рае, о саде жизни в его „таинственном касании мирам иным”, о религиозной этике любви к жизни и признания своей вины и ответственности перед всем и всеми. Всего этого Стемповский во вторично-рецептивном, шестовском видении Достоевского не находит в русской классике.

При всем том у Стемповского нет склонности к принятию шестовской экзистенциальной „философии трагедии”, в качестве иллюстрации которой русский мыслитель-экзистенциалист берет образы из Достоевского. Польский автор - это, в первую очередь, холодный скептик-наблюдатель, предпочитавший сохранять верность классическим канонам средиземноморской культуры и потому не разделявший „lugere et destari” („скорбеть и проклинать” - Л. М.) библейского Иова, которое Шестов считал новым способом философствования. В связи с этим, по словам Я. Томковского,

Traktował (Stempowski - Л. M.) podejrzliwie Tertuliana, który kazał chrzecijaństwu wybierać między Atenami a Jerozolimą. Taki punkt widzenia wydawał mu się z gruntu fałszywy. Sam wolał wybierać między Rzymem a Jerozolimą, decydując się naturalnie na pierwszą możliwość. Akceptował zresztą Rzym dawnych pisarzy, a nie współczesnych papieży, dla tradycji religijnych „wiecznego miasta” znajdując niewiele zrozumienia ${ }^{14}$.

Закономерно, что попытка Стемповского объяснить польские стереотипы Достоевского его базовыми художественно-философскими постулатами не приводит к желаемому результату. Этот отрицательный результат, на наш взгляд, поучителен не только в частном историко-литературном примере, но и в теоретических обобщениях, так как художественно-философская концепция автора неравномерно отражается в разных сегментах романного текста. Сцены и персонажи,

14 J. T o m k o w s k i, Jerzy Stempowski, Warszawa 1991, c. 12. 
далеко отстоящие от художественно-философской концепции автора романа, согласно емкой метафоре Кундеры, выполняют роль „окон” 15 . Именно „оконную” функцию в текстах Достоевского исполняет, на наш взгляд, „польская" тема, не обнаруживающая прямых причинноследственных связей с художественной философией писателя. Ближе к реальному положению вещей объяснение казуса „поляков Достоевского" не индивидуально-мировоззренческим или этико-философским, а эстетико-социологическим фактором эпохи, вызвавшей к жизни обилие клишированных образов поляков в русской публицистике, беллетристике и даже в литературной классике ${ }^{16}$. Но и названный фактор не представляется исчерпывающим. Правдоподобно предположение Стемповского, что польские персонажи не были взяты Достоевским из жизни, а представляли искусственно смоделированные конструкции, типологически подобные мольеровскому Тартюфу. Польские типажи „сделаны” скорее по канонам классицизма, чем реализма. Точно так же, как Пушкин противопоставлял „характерам” Шекспира „типы” Мольера, Достоевский воспроизводит упрощенный тип-маску персонажа, сводящийся к двум-трем доминантным признакам и в общей конструкции романа полярно противоположный шекспировски и шиллеровски полнообъемным характерам Достоевского.

Но было бы преувеличением полагать, что „ограниченными" в произведениях Достоевского представлены только польские персонажи. Нам не кажется оправданным допущение об их „изолированном” статусе в романах Достоевского. Панорамный взгляд на Книгу Восьмую Митя романа Братья Карамазовы демонстрирует то, что комический дуэт - „прежний” и „бесспорный” жених Грушеньки пан Муссялович и его спутник Врублевский - органично вписывается в галерею мошенников, плутов и авантюристов: это „старый купчишка, развратный мужик и городской голова” Иван Кузьмич Самсонов с лицом „как у истукана"17, купец-лесоторговец Горсткин по прозвищу Лягавый, которому надо смотреть на бороду, чтобы понять, плутует ли он или говорит правду ${ }^{18}$, наконец, хозяин двора в Мокром Трифон Борисыч, „имевший дар быстро изменять лицо свое на самое подобострастное выражение, когда чуял взять выгоду" 19 . Этот ряд личин, масок, предстающий перед Митей в период его хаотических метаний, подобен

${ }^{15}$ М. К у н д е р а, Нарушенные завещания: эссе, Санкт-Петербург 2005, с. 225-230.

${ }_{16}$ См. об этом: В. А. Х о р е в, Польский вопрос в России после восстания 1863 г., [в:] его же, Польша и поляки глазами русских литераторов..., указ. соч., с. 78-101.

17 Ф. М. Д о с т о е в с к и й, Собрание сочинений $b$ двенадиати томах, т. 11, Москва 1982, c. 435.

18 Там же, с. 445.

19 Там же, с. 486. 
даже не столько комическим героям Мольера, сколько комическо-гротескному аду поэмы Гоголя Мертвые души, в котором, как известно, представлены персонажи „один пошлее другого” 20, и странствующий герой которого, подобно мечущемуся Мите Карамазову, вправе сказать словами Ницше: „Поистине, друзья мои, я хожу среди людей как среди обломков и отдельных частей человека!"21. Гоголевский код книги Митя подчеркнут самим автором - в главе Прежний и бесспорный на фоне скучающей польской пары вниманием окружающих завладевает помещик Максимов, предпринимающий рискованную попытку само-пиара - рекомендуясь „тем самым" помещиком Максимовым, высеченным гоголевским Ноздревым. Сам по себе этот дантовско-гоголевский круг персонажей не указывает на наличие критериев избирательности по национальному признаку, в которых подозревает Достоевского Стемповский.

Второстепенный или третьестепенный, заведомо „эпизодический” статус польской темы в романе Братья Карамазоъы также не представляется самоочевидным. Конечно, читатель обращает внимание на то, что имя и фамилия польского „прежнего” жениха Грушеньки практически на протяжении всего присутствия этого персонажа на сцене являются сокрытыми. Однако его сюжетное появление компенсируется значимым и звучным местоимением: „На диване сидел он...”22. Но кто „он”?

В упомянутом адском кругу авантюристов и мошенников Книги 8 Митя оказывается один из главных героев романа Федор Павлович Карамазов в последние минуты его жизни. В организуемой Достоевским последовательности событий неслучайно появление польского жениха Грушеньки после смерти Федора Павловича. С Митиной перспективы возникает поразительное сходство между поляком и его отцом - возникает идентичное отношение Мити к обоим фигурам и сходное внезапное, практически одновременное исчезновение обоих со сцены. „Прежний” и „бесспорный” поляк Грушеньки есть не что иное, как фантомный, инобытийный „отец” Мити Карамазова. Оба, Федор Павлович и поляк, - „конкуренты” Мити, к обоим Митя ревнует, явно или скрыто, и, следовательно, испытывает неприязнь. В обоих случаях неприязнь проявляется в форме зрительного отторжения, при виде Федора Павловича всеохватывающего: „Весь столь противный ему профиль старика, весь отвисший кадык его, нос крючком..." 23, при

\footnotetext{
${ }^{20}$ Н. В. Г о г о л ь, Собрание сочинений в семи томах, т. 5, Москва 1985, с. 469.

21 Ф. Н и ц ш е, Сочинения В двух томах, т. 2, Москва 1990, с. 100.

22 Ф. М. Д о с т о е в с к и й, указ. соч., с. 489.

23 Там же, с. 462.
} 
созерцании поляка („обрюзглое лицо”, „востренькие усики”, „дрянненький паричок" 24) рассудочное „я" Мити пытается сдержать антипатию, постепенно завладевающую эмоциональной стороной его души: "«Ну что же такое, ну и хорошо, что он курит трубку», созерцал Митя... «значит так и надо, коли парик», - блаженно продолжал он созерцать" 25 .

Польский персонаж в подсознании Мити становится „отголоском", „эхом" Отца, следовательно, он лишен бытийной самостоятельности. Неслучайно он назван „привидением". В его образе присутствует мотив оборотничества, превращения, как, например, в одноименном рассказе Франца Кафки, герой которого превращается в насекомое. "OH" в романе Достоевского превращается в „оно":

Теперь с одним по крайней мере привидением, страшилищем покончено: этот ее „прежний”, ее бесспорный, фатальный человек этот исчез, не оставив и следа. Страшное привидение обратилось вдруг во что-то такое маленькое, такое комическое: его снесли руками в спальню и заперли на ключ. Оно никогда не воротится ${ }^{26}$ (курсив - Л. М.).

Таков механизм метаморфозы и слияния двух образов: главного - Федора Павловича Карамазова и эпизодического - польского.

Посмертный образ Федора Павловича приобретает фантастический „полонизированный” колорит. Об этом также свидетельствует странная и произнесенная невпопад фраза прокурора Ипполита Кирилловича, сказанная о Федоре Павловиче Карамазове: „ведь мы все его знали: «Он между нами жил...»" 27 - начало известного стихотворения Пушкина о Мицкевиче. К Мицкевичу, конечно, образ жизни Федора Павловича Карамазова не имеет никакого отношения, но показательно то, что таким образом в образ Карамазова-старшего без каких-либо объяснений вносится польский колорит.

Но вернемся к Стемповскому. Практически одновременно с очерком Поляки в романах Достоевского появляется эссе-криптопамфлет Пан Иовяльский и его наследники (Pan Jowialski i jego spadkobiercy). Последний некоторые читатели восприняли как текст с ключом, с зашифрованными смыслами и посланиями читателю, далеко отходящими от смыслов буквальных ${ }^{28}$. Историко-литературный анализ комедии выдающегося польского драматурга XIX века Александра Фредро содержал в себе скрытую критику политической системы Польши времен

24 Там же, с. 492-493.

25 Там же, с. 493.

26 Там же, с. 513.

27 Ф. М. Д о с т о е в с к и й, указ. соч., т. 12, с. 218.

28 J. T о m k o w s k i, указ. соч., с. 7. 
Юзефа Пилсудского, а сам образ пана Иовяльского был чем-то вроде маски польского диктатора. По аналогии с упомянутым текстом эссе о Достоевском скрывает возможность прочтения наоборот. В частности, заставляет задуматься высказывание о Ежи Стемповском Марии Домбровской из дневника за 1935 год: „Aż dziwnie, że człowiek w niczym prócz siebie nie potrafi nic dobrego zobaczyć. I aż dziwnie, co robi w Polsce, którą uważa za tak nikczemną i spodlałą" 29 . Это свидетельство позволяет предположить, что сатирические польские эпизоды Достоевского воспринимались Стемповским даже не без некоторого сочувствия. Так или иначе, мессианизм, идея „Польши - Христа народов”, бывшая символом веры польских эмигрантов и деятелей национально-освободительного движения XIX века, романтизм с его национально-патриотическими императивами однозначно не был идеологическим кредо Стемповского, его он считал архаикой, признаком культурного отставания.

В поэтике романа Братья Карамазовы польская тема ориентирована на кардинальный архетип всего произведения - архетип Отцовства, тесно связанный в мировой культуре с представлением о порядке мира и мировой иерархии. Для польской литературы XX века, к которой принадлежал Стемповский, Достоевский может считаться неявным предтечей „литературы насмешки", гротескно-сатирического направления, разоблачавшего мифы „польскости”, выступающего с критикой „школы недействительности”, занимавшейся производством псевдоценностей и псевдоидеалов. Одним из видных представителей этой школы насмешки над действительностью, а значит, „союзником" Достоевского, может считаться Витольд Гомбрович, читавший книгу Братья Карамазовы практически синхронно с написанием романа Транс-Атлантик, в котором жесткому и скандальному осмеянию подвергнуты мифы „польскости". Симптоматично, что в этом романе на смену дорогому сердцу поляка мифу Отчизны (производному от Отца) приходит неомиф „земли обетованной”, маркируемой Гомбровичем с помощью неологизма „Сынчизна".

\section{Библиография}

Б а р а н о в А. И., Стефран Жеромский и Ф. М. Достоевский, [в:] Литературные связи славянских народов, Ленинград 1988.

Г о г о л ь Н. В., Собрание сочинений в семи томах, т. 5, Москва 1985.

Д о с т о е в с к и й Ф. М., Собрание сочинений В двенадцати томах, т. 11, Москва 1982. Д у д к ин В. В., Достоевский - Ниище (Проблема человека), Петрозаводск 1994.

29 Там же, с. 39-40. 
3 е м с к о в В. Б., Образ России „на переломе” времен (Теоретический аспект: рецепция и репрезентация „другой” культуры), „Новые российские гуманитарные исследования" 2006, № 1.

К у н д е р а М., Нарушенные завещания: эссе, Санкт-Петербург 2005.

Л и п п м а у У., Общественное мнение, Москва 2004.

М их а ль с к а я Н. П., Россия и Англия: проблемы имагологии, Москва 2012.

Н е л ь с о н Т., Психология предубеждений. Секреты шаблонов мышления, восприятия и поведения, Санкт-Петербург 2003.

Н и ц ш е Ф., Сочинения в двух томах, т. 2, Москва 1990.

П ш е б и н д а Г., Между Краковом, Римом и Москвой. Русская идея $\mathbf{b}$ новой Польше, Москва 2013.

У г л и к Я., Образ поляков в романах и публицистике Ф. М. Достоевского, “Toronto Slavic Quaterly", summer 2011, nr 37, c. 142.

Х о р е в В. А., Ф. Достоевский в сознании польских писателей ХХ века, [в:] его же, Восприятие России и русской литературы польскими писателями. Очерки, Москва 2012, c. 71-98.

Х о р е в В. А., Польша и поляки глазами русских литераторов. Имагологические очерки, Москва 2005.

S t e m p o w s k i J., Polacy w powieściach Dostojewskiego, [в:] его же, Eseje dla Kassandry, Gdańsk 2005, c. 283-284.

W e d e m a n n M., Polonofil czy polakożerca. Fiodor Dostojewski w piśmiennictwie polskim lat 1847-1897, Poznań 2010.

Ż e r o m s k i S., Snobizm i postęp, [в:] электронный ресурс: http://literat.ug.edu.pl/ xxx/snobizm/0002.htm (18.12.2015). 
